\title{
Performance Analysis of Indonesia's Mining Sector Price Index
}

\author{
Hastra Reza Satyatama', Riwi Sumantyo² \\ Sebelas Maret University \\ 'hastrareza@gmail.com, 2riwi_s@yahoo.com
}

\begin{abstract}
Subprime mortage's crisis in United States 2008 giving effect to the global capital markets especially the stock price index of the mining sector Indonesia. This research analyzes the effect of BI Rate, exchange rate, world gold price, crude oil price, and Dow Jones Industrial Average on the stock price index of the mining sector. This research employs time series monthly data of 2009-20I6 with Error Correction Model-Engle Granger (ECM-EG) as the method. The analysis showed that the $B I$ rate, exchange rate and world gold price, has a negative and significant effect. World oil prices affect positively but not significant meanwhile the Dow Jones Industrial Average has a positive and significant impact on the stock price index of the mining sector. For investors in the mining sector, should pay attention to the exchange rate of the rupiah and Dow Jones Index significantly in the mining sector of the stock price index.
\end{abstract}

Keywords: stock price index, mining sector, error correction model

\begin{abstract}
Abstrak
Krisis subprime mortage di Amerika Serikat 2008 memberi pengaruh pada pasar modal global terutama indeks harga saham sektor pertambangan Indonesia. Penelitian ini menganalisis pengaruh $\mathrm{BI}$ Rate, nilai tukar, harga emas dunia, harga minyak mentah, dan Dow Jones Industrial Average terhadap indeks harga saham sektor pertambangan. Penelitian ini menggunakan data bulanan seri time 2009-2016 dengan metode Error Correction Model-Engle Granger (ECM-EG) sebagai metode. Analisis menunjukkan bahwa BI rate, nilai tukar dan harga emas dunia, memiliki pengaruh negatif dan signifikan. Harga minyak dunia berpengaruh positif namun tidak signifikan sedangkan Dow Jones Industrial Average memiliki dampak positif dan signifikan terhadap indeks harga saham sektor pertambangan. Bagi investor di sektor pertambangan, harus memperhatikan nilai tukar rupiah dan Indeks Dow Jones secara signifikan di sektor pertambangan dari indeks harga saham.
\end{abstract}

Kata Kunci: indeks harga saham, sektor pertambangan, model koreksi kesalahan 
Performance Analysis of Indonesia's...

Hastra Reza Satyatama, Riwi Sumantyo

\section{INTRODUCTION}

The mining sector becames one of the main commodities in the modern economy, especially in the sub-sectors of energy, they are oil and coal. It is because the vital roles of oil and coal which become the main energy sources for most of the production process and economic activities in all over the global. The mining sector is one of the underpinning of economic development of a country, because of its role as a provider of energy resources that are indispensable for the growth of the economy of a country. The potential of rich natural resources will be able to foster the opening of companies to conduct exploration of mining resources.

Minning companies need huge acapital in the exploring natural resources in developing countries for the sake of minning develpoment. Many mining companies entries the capital market to strengthen their financial position. In the stock market, it can be seen from the amount of emitten in this sector which is getting increased every year as well as the value of market capitalization which is big enough in the stock market. In 2016, the amount of emitten of the mining sector consisted of sub-sector of coal mining as many as 23 companies, sub-sector of crude petroleum and natural gas production as many as 9 companies, sub-sector of metal and mineral mining as many as 9 companies and sub-sector of land/stone quarrying as many as 2 companies.

Figure I. IDX Mining 2009-20 I6

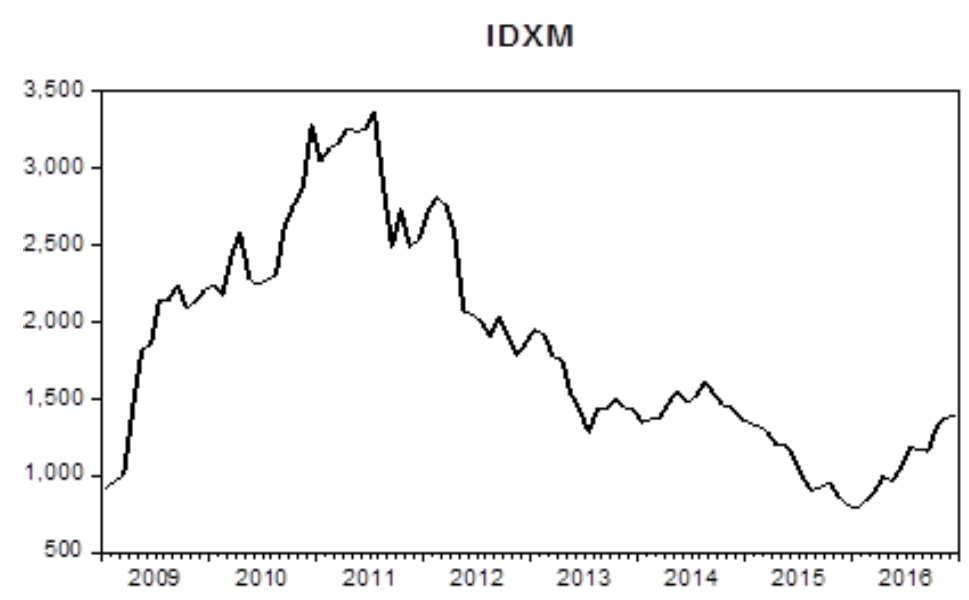

Source: www.investing.com, 2016

In 2009, the fast enough growth of the mining sector was inseparable from the supports of mining commodities such as copper and aluminum, which increased in the international market. It was reinforced by a statement of Sidarta (2010) that toward 2009, especially in Asian zona, the economic growth underwent a big increase and was 
successfully in increasing the commodity demand, so it increases the oil price and the mining sector. In several recent years, the stock price index of the mining sector decreased, exactly in the period of 2011 up to 2015. It could happen because the global oil price that becomes the reference of the mining sector also decreased. It made the investors choose to avoid risk, moreover, the investors in Indonesia tend to profit taking to be able to realize the short-term profit which will have an impact on the Composite Stock Price Index (IHSG), in another side, the mining stock has big enough weight on the Indonesia stock exchange index. Especially in 2015, the stock of the mining sector was still be pressured in line with no recovery of the coal price due to decreased demand, in line with the export country destination such as China was undergoing an economic sluggish.

After undergoing a dilution in 2015, now, the mining stocks can be the supports of the reinforcement of Indonesia stock index. In 2016, the stock price index of the mining sector increased enough significantly. The increase in the stock price of the mining sector was inseparable from the global oil price, which began to recover. Since the beginning of the year up to 14 October 2016, the stock index of the mining sector had increased 53.35\%, defeated the Composite Stock Price Index (IHSG), which only increased $17.37 \%$ in the similar period.

There have been many studies conducted to analyze the factors, which influence the stock price index and some opinions occurred regarding them. There are many studies on the factors, which influence stock price index in many countries such as The United States, Brazil, Russia, India, and China. Kilian and Park (2007) conducted a research on the influence of the global oil price on the aggregate profit level of the United States stock market. The result of their research was that the change in the global oil price had two influences on the stock market in the United States.

The result was in line to what Sirucek (2012) said about a positive relation between the oil price and the stock price index of the United States. Besides Russia and the United States, this argumentation was also reinforced by the opinion from Ono (20II) that found a proof that the oil price also responded positively on stock return in the stock exchanges of China and India. Meanwhile, in Brazil, there was no significant response. 
Performance Analysis of Indonesia's...

Hastra Reza Satyatama, Riwi Sumantyo

Whereas, there have been many studies on the factors which influence the stock price index in Indonesia. Tjandrasa and Sutjiati (2016) stated that the global gold price, the crude oil price and the interest rate simultaneously influence the composite stock price index. Achmad and Ramli (2013) found results that inflation did not influence IHSG, Rupiah exchange rate and the reserves of foreign exchange income influenced IHSG, SBI (Bank Indonesia Certificates) rate partly and influenced IHSG negatively and Dow Jones Index influenced IHSG partly.

Then, a research conducted by Gumilang, et.al. (2014) revealed that the variable of $\mathrm{BI}$ interest rate, US Dollar exchange rate, the gold price and the global oil price influenced simultaneously the composite stock price index. Prasetiono (2010) stated that the economic growth and the oil price influenced the stock price of LQ45 in short term. Meanwhile, in long term, the stock price of LQ45 was influenced by SBI rate and the economic growth. Agustin (2016) found results that the USD exchange rate and $\mathrm{SBI}$ interest rate influenced significantly the stock price index of the mining sector, meanwhile, inflation did not influence significantly the stock price index of the mining sector. Related to those results, the researcher will explore more the factors, which influence the stock price index especially the mining sector in BEI.

There are many factors that influence the stock price index of the mining sector in this research including factors from foreign countries such as the global gold price, the global oil price, and Dow Jones Index. Meanwhile, the domestic factors are $\mathrm{BI}$ Rate and Rupiah exchange rate. Seen from a very important contribution as the supports of the reinforcement of Indonesia stock index and to much gap research, so researchers want to examine what factors are affecting the mining sector of the stock price index.

\section{METHOD}

This research analyzed the influences of $\mathrm{BI}$ Rate, Rupiah exchange rate, the global gold price, the oil price and Index Dow Jones against stock price index the mining sector. The data used are secondary data. The periods used in the research are data from January 2009 up to December 2016. The method used in the research is quantitative method using the basic regression model Error Correction Model (ECM). Error Correction Model is a model used to know the short-term and long-term of independent variable on the dependent variable. 
The short-term dynamics is explained by mechanism of mistake correction. Meanwhile, if the mechanism of mistake correction is a valid model, the variables used are a cointegration association, in contrary, if the variables used are not cointegrated, the residual of ECM is nonstationary and the specification of the model is not valid. The cointegration model is intended to test the stationarity of cointegration regression residual. This testing is important in the use of dynamic model of ECM because if the cointegration regression residual is stationary, the residual can form a short-term model of ECM, which had been developed by Engle-Granger.

Below is the preliminary model for the equation of long-term equation used in this research:

$$
\begin{array}{ll}
\text { LIDXM }=\alpha+\beta_{1} \text { BIRATE }-\beta_{2} \text { LEXRATE }-\beta_{3} \text { LGOLD }-\beta_{4} \text { LOIL }-\beta_{5} \text { LDJIA } \\
\text { Description: } \\
\begin{array}{ll}
\text { LIDXM } & =\text { Stock price index of the mining sector } \\
\text { BIRATE } & =\text { Interest rate } \\
\text { LEXRATE } & =\text { Rupiah exchange rate } \\
\text { LGOLD } & =\text { The global gold price } \\
\text { LOIL } & =\text { The global oil price } \\
\text { LDJIA } & =\text { Dow Jones Index }
\end{array}
\end{array}
$$

The next step was finding the residual value called as Error Correction Term (ECT). Then, the cointegration test was conducted to test whether the residual of ECT is stationary or not. The interrelatedness of cointegration test and ECM was traced through significant ECT statistically. After several steps above, the next step is analyzing data using Error Correction Model (ECM), with a short-term equation such as follows:

$$
\begin{aligned}
& \Delta L I D X M=\beta_{1} \Delta B \text { Irate }_{t}-\beta_{2} \Delta \text { LEXRate }_{t}-\beta_{3} \Delta \text { LGold }_{t}-\beta_{4} \Delta \text { LOil }+\beta_{5} \Delta L D J I A- \\
& \text { ECT } \\
& \text { Description: } \\
& \Delta \text { LIDXM = Dependent variable in the } \mathrm{I}^{\text {st }} \text { difference } \\
& \mathrm{ECT}_{\mathrm{t}-\mathrm{I}} \quad=\text { Residual of short-term eqution in the period of } \mathrm{t}-\mathrm{I}
\end{aligned}
$$


Performance Analysis of Indonesia's...

Hastra Reza Satyatama, Riwi Sumantyo

\section{RESULT AND DISCUSSION}

The first step conducted was the test of selection of function model form using MWD Test. This testing is necessary to know which model is the most proper to be used in this the research. Types of model tested in this research are linear model and log linear model. Hypothesis to test the linear model in the research is if $\mathrm{ZI}$ is statistically significant, $H_{0}$ is rejected, meanwhile, if $Z I$ is not statistically significant, $H_{0}$ is accepted. So it is in the linear log model in which if $Z 2$ is statistically significant, $H_{0}$ is rejected, meanwhile, if $Z 2$ is not statistically significant, $H_{a}$ is accepted. The results of MWD test that had been conducted at Table I.

Table I. MWD Test Linear Model

\begin{tabular}{ccccc}
\hline Variable & Coefficient & Std. Error & t-Statistic & Prob. \\
\hline ZI & $-14 \mid I .753$ & $29 \mid .5885$ & -4.841594 & 0.0000 \\
\hline \multicolumn{5}{c}{ Source: Result processed }
\end{tabular}

The results of MWD test in the pada model linier revealed that $\mathrm{ZI}$ is statistically significant in the level of significance of $5 \%$ viewed from its probability that is 0.0000 . It means that $H_{0}$ is rejected or the linear model cannot be used in this research.

Table 2. MWD Test Model Log Linear Model

\begin{tabular}{ccccc}
\hline Variable & Coefficient & Std. Error & t-Statistic & Prob. \\
\hline Z2 & 0.000264 & 0.000137 & 1.919967 & 0.0581 \\
\hline \multicolumn{2}{c}{ Source: Result processed } &
\end{tabular}

The result of MWD test in the linear log model showed that Z2 is not statistically significant. It means that $\mathrm{H}_{\mathrm{a}}$ is accepted or the linear model can be used in this research. Then, Unit Root Test was conducted to test the stationarity in the data. The data stationarity is an important thing because the use of data that is not stationary in the model can cause spurious regression. The unit root test in this research used the test of Augmented Dickey Fuller (ADF). A variable is said as stationary if the value of t-statistic of ADF is less than the critical value of MacKinnon, or the probability is less than the significance degree value.

Based on Table 3, variables of stock price index of the mining sector (LIDXM), BI Rate (BIRATE), Rupiah exchange rate (LEXRATE), the global gold price (LGOLD), the global oil price (LOIL), and Dow Jones Index (LDJIA) has an absolute value of ADF test which is less than the critical value of $5 \%$ and the probability value which is more 
than 0.05 , therefore, it can be concluded that all variables have not been stationary in the level degree.

Table 3. Unit Root Test at Level

\begin{tabular}{ccccc}
\hline Variable & ADF Test & Critical Value 5\% & Probability & Description \\
\hline LIDXM & $-1.55 I I 43$ & -2.892200 & 0.5035 & Not Stationary \\
BIRATE & -1.643938 & -2.892879 & 0.4563 & Not Stationary \\
LEXRATE & -0.491940 & -2.892536 & 0.8871 & Not Stationary \\
LGOLD & -1.733467 & -2.892536 & 0.4113 & Not Stationary \\
LOIL & -2.073794 & -2.892536 & 0.2557 & Not Stationary \\
LDJIA & -1.546563 & 2.892200 & 0.5058 & Not Stationary \\
\hline
\end{tabular}

Source: Result processed

The integration degree test is necessary to be conducted because not all stationary variables are in the level degree. The integration degree test was conducted to know the ordinal number of the differentiation level of all variables that had been stationary. In this research, the integration degree test also used Augmented Dickey Fuller. The variable data which are not stationary in the level degree will be tested until the ordinal number of all variable data that will be stationary. Below are the results of the integration degree test in the method of Augmented Dickey Fuller in the first differention level:

Table 4. Integration Degree Test at First Difference

\begin{tabular}{ccccc}
\hline Variable & ADF Test & Critical Value 5\% & Probability & Keterangan \\
\hline LIDXM & -7.268310 & -2.892536 & 0.0000 & Stationary \\
BIRATE & -6.359547 & -2.892536 & 0.0000 & Stationary \\
LEXRATE & -6.960917 & -2.892536 & 0.0000 & Stationary \\
LGOLD & -7.361023 & -2.892536 & 0.0000 & Stationary \\
LOIL & -7.498578 & -2.892536 & 0.0000 & Stationary \\
LDJIA & -11.42175 & -2.892536 & 0.0001 & Stationary \\
\hline
\end{tabular}

Source: Result processed

Based on Table 4, the result of integration degree test in the first differention level is that all variables have been stasionary. Therefore, the variables used in the research have a long-term relation. After obtaining the results from the stationarity test as the necessary requirements from the cointegrated regression, the residual of the model must also be stationary. The stationarity of the model residual is a sufficient requirement of cointegrated regression. In econometrics, cointegrated variable is said as being in a balanced long-term condition. The model of ECM also requires the stationarity of residual. 
Performance Analysis of Indonesia's...

Hastra Reza Satyatama, Riwi Sumantyo

Table 5. Residual Test

\begin{tabular}{ccccc}
\hline Variable & Coefficient & Std. Error & t-Statistic & Prob. \\
\hline ECT $(-I)$ & -0.168784 & 0.057447 & $-2.93810 I$ & 0.0042 \\
C & 0.001905 & 0.007373 & 0.258315 & 0.7967 \\
\hline
\end{tabular}

Source: Result processed

From the regression equation on Table 5, the residual value will be obtained. Then, this residual value will be tested using Augmented Dickey Fuller to know whether the residual value is stationary or not. Table 6 shows the results of the Augmented Dickey Fuller test.

Table 6. Residual Unit Root Test

\begin{tabular}{|c|c|c|c|}
\hline & & t-Statistic & Prob.* \\
\hline \multicolumn{2}{|c|}{ Augmented Dickey-Fuller test statistic } & $-2.938 \mathrm{IOI}$ & 0.0448 \\
\hline \multirow[t]{3}{*}{ Test critical values: } & I\% level & $-3.50 \mid 445$ & \\
\hline & $5 \%$ level & -2.892536 & \\
\hline & $10 \%$ level & $-2.58337 \mid$ & \\
\hline
\end{tabular}

Source: Result processed

From the cointegration test using the method of Augmented Dickey Fuller, it showed that the probability value of residual variable (ECT-I) is 0.0042 . In the unit root test, it can be known the residual variable before $\mathrm{t}-\mathrm{I}$ has been stasionary in the degree level with the t-statistic of ADF is as much has -2.938I0I more than the critical value $5 \%$ that is -2.892536 with the probabilitas is as much s 0.0448 , therefore, it can be known that the residual has been stationary in the degree level. Therefore, it can be concluded that the regression is a cointegrated regression. The results of residual testing on Table 5 and Table 6 showed that the the residual is stasionary in the degree level and statistically significant, therefore, the dependent variable in this research can be used in he short-term model of ECM Engle Granger.

The value of Adjusted $R$-squared showed value as much as 0.34 I7II that means $34.17 \%$ of independen variable can explain the dependent variable; meanwhile, the rest is explained by other variables out of the research. Coefficient ECT(-I) is as much as 0.139716 with significance as much as 0.0110 which is suitable with the theory that the coefficient ECT(-I) is negative and significant, therefore, ECM EG can be used. Thus, the specification of the model used in this research is valid and ECM EG has passed all classica asumption tests. 
Table 7. Short Term ECM

\begin{tabular}{|c|c|c|c|c|}
\hline Variable & Coefficient & Std. Error & t-Statistic & Prob. \\
\hline D(BIRATE) & -5.030538 & 3.515995 & -1.430758 & 0.1560 \\
\hline $\mathrm{D}($ LEXRATE) & -1.054380 & 0.367080 & -2.872345 & 0.0051 \\
\hline $\mathrm{D}($ LGOLD) & 0.360161 & 0.193904 & 1.857420 & 0.0666 \\
\hline $\mathrm{D}(\mathrm{LOIL})$ & 0.056519 & 0.087488 & 0.646014 & 0.5199 \\
\hline $\mathrm{D}(\mathrm{LDJIA})$ & 0.852327 & 0.198636 & 4.290890 & 0.0000 \\
\hline ECT(-I) & -0.139716 & 0.053801 & -2.596886 & 0.0110 \\
\hline R-squared & 0.376727 & Mean dependent var & & 0.004279 \\
\hline Adjusted R-squared & $0.34|7| I$ & S.D. dependent var & & 0.082028 \\
\hline S.E. of regression & 0.066553 & Akaike info criterion & & -2.520549 \\
\hline Sum squared resid & 0.394213 & Schwarz criterion & & $-2.35925 \mid$ \\
\hline Log likelihood & $|25.726|$ & Hannan-Quinn criter. & & -2.455373 \\
\hline Durbin-Watson stat & 1.816417 & & & \\
\hline
\end{tabular}

Source: Result processed

The above tests showed the results of estimation of ECM in short term, in which each variable has an influence suitable with the hypothesis. The result of ECM regression can be written as:

$$
\begin{aligned}
\Delta \text { LIDXM }_{\mathrm{t}}= & -5.030538 \Delta \text { BIRATE }_{\mathrm{t}}-1.054380 \Delta \text { LEXRATE }_{\mathrm{t}}+0.36016 \mathrm{I} \Delta \mathrm{LGOLD}_{\mathrm{t}}+ \\
& 0.056519 \Delta \mathrm{LOIL}+0.852327 \Delta \mathrm{LDJIA}^{-}-0.139716_{\mathrm{t}-1}
\end{aligned}
$$

Table 8 showed the results of ECM estimation for long term with R-squared as much as 0.875933 that means $87.5 \%$ of dependent variable can be explained by the independent variable. Meanwhile, $12.5 \%$ of the rest is explained by other variables outsides the independent variable in this research.

\section{Table 8. Long Term ECM}

\begin{tabular}{crcrr}
\hline \multicolumn{1}{c}{ Variable } & Coefficient & Std. Error & t-Statistic & \multicolumn{1}{c}{ Prob. } \\
\hline C & 31.57636 & 2.498360 & 12.63883 & 0.0000 \\
BIRATE & -1.102116 & 2.367803 & -0.465459 & 0.6427 \\
LEXRATE & -2.822207 & 0.301007 & -9.375880 & 0.0000 \\
LGOLD & -0.344991 & 0.156836 & -2.199696 & 0.0304 \\
LOIL & 0.025721 & 0.079747 & 0.322539 & 0.7478 \\
LDIIA & 0.470439 & 0.147077 & 3.198583 & 0.0019 \\
\hline R-squared & 0.875933 & Mean dependent var & & 7.435705 \\
Adjusted R-squared & 0.869041 & S.D. dependent var & & 0.392858 \\
S.E. of regression & 0.142168 & Akaike info criterion & & -1.003148 \\
Sum squared resid & 1.819067 & Schwarz criterion & & -0.842876 \\
Log likelihood & 54.15109 & Hannan-Quinn criter. & & -0.938363 \\
F-statistic & 127.0834 & Durbin-Watson stat & & 0.330790 \\
Prob(F-statistic) & 0.000000 & & \\
\hline Source: Resul processed & & &
\end{tabular}

Source: Result processed 
Performance Analysis of Indonesia's...

Hastra Reza Satyatama, Riwi Sumantyo

After conducting estimation of long term Error Correction Model (ECM), it obtained an equation and interpretation as follows:

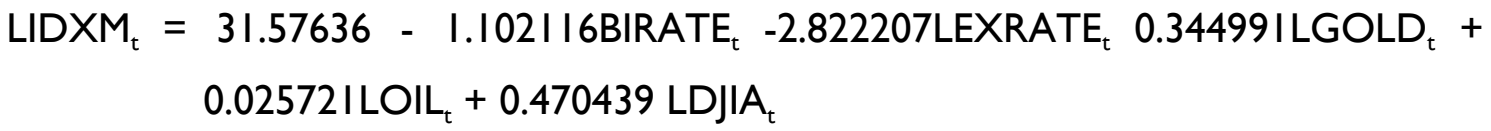

\section{Discussion}

From the result, result of the short-term of the coefficient of BI Rate (BIRATE) on the stock price index of the mining sector (LIDXM) is negative with the coefficient value -5.030538 that means every incident of increase in BI Rate (BIRATE) as much as I\% (ceteris paribus), it will decrease the stock price of the mining sector as much as $5.030538 \%$. Than, on the long-term the coefficient of BI Rate (BIRATE) on the stock price index of the mining sector (LIDXM) is negative with the coefficient value I.102116 that means every incident of increase in BI Rate (BIRATE) as much as $1 \%$ (ceteris paribus), it will decrease the stock price of the mining sector as much as I.102116\%.

The result above was accepting initial hypothesis that $\mathrm{BI}$ rate has negatively effect with the stock price index of the mining sector. Prasetiono (2010) shows that interest rates have a negative influence on stock prices at both the long term and in the short term. The research also supported by Kewal (2012) of which variable interest rate affect the stock price index in the negative but not significant. Thus, the relationship between interest rate with stock prices is negative, because if there is a rise in the interest rate investors will transfer its assets in the form of deposits that ultimately the selling action will lower the price of the stock.

From the result, on the short term The coefficient of Rupiah exchange rate (LEXRATE) on the stock price index of the mining sector (LIDXM) is negative with the coefficient value as much as -1.054380 , that means every increase in Rupiah exchange rate as much as $1 \%$, it will decrease the stock price of the mining sector as much as $1.054380 \%$. Than on the long term the coefficient of Rupiah exchange rate (LEXRATE) on the stock price index of the mining sector (LIDXM) is negative with the coefficient value as much as -2.822207 , that means every increase in inflation, it will decrease the stock price of the mining sector.

The result was accepting initial hypothesis that rupiah exchange rate gas negatively effects with the stock price index of the mining sector. This occurs because 
in the research period, the exchange rate tends to depreciate the rupiah exchange value or continue to decline. Sunariyah (20II) found depreciating dollars will raise the cost of imported raw materials and increases in interest rates although it can increase the value of exports. The weakening of the rupiah exchange rate against foreign currencies had a negative influence on economics and capital markets. Prasetiono (2010) suggests there is a negative relationship exchange rate against the stock price index. The weakening of the exchange rate gives negative signals to investors. Investors will sell his shares, as investors tend to avoid the risk of the investments made.

From the result, on the short term the coefficient of the global gold price (LGOLD) on the stock price index of the mining sector (LIDXM) is positive with the coefficient value is as much as $0.36016 \mathrm{I}$, that means every increase in the global gold price as much as $1 \%$ (ceteris paribus), it will increase the stock price index of the mining sector as much as $0.360161 \%$. Meanwhile on the long term The coefficient of the global gold price (LGOLD) on the stock price index of the mining sector (LIDXM) is negative with the coefficient value is as much as -0.34499 , that means every increase in the global gold price, it will increase the stock price index of the mining sector.

Sunariyah (20II) stating that the rise in the gold price will encourage a decline in stock price index. because the investors will choose to invest in gold, because with a lower risk investment in gold provide a higher return than stocks. Yuswandi (2012) stating the price of gold had a negative influence against share price BSDE. When stock prices are falling, it's usually because the performance doesn't match the expectations of investors, the owners of idle money will switch to a mode other than stock investments. Many investors who promptly chose gold as an alternative investment.

On the short term The coefficient of the global oil price (LOIL) on the stock price index of the mining sector (LIDXM) is positive with the coefficient value is as much as 0.056519 , that means every increase in the global oil price as much as $1 \%$ (ceteris paribus), it will increase the stock price index of the mining sector as much as $0.056519 \%$. Its same with the result on the long term, the coefficient of the oil price global (LOIL) on the stock price index of the mining sector (LIDXM) is positive with the coefficient value is as much as 0.025721 , that means every increase in the global oil price, it will increase the stock price index of the mining sector as much as $0.025721 \%$ but not significantly with the probability value as much as 0.7478 . 
Performance Analysis of Indonesia's...

Hastra Reza Satyatama, Riwi Sumantyo

The result has accepted hypothesis initial that's the global oil price had positively effect with the stock price index of the mining sector. Similar to the theory advanced by Sidarta $(2010)$ stating that world oil prices a positive effect on stock prices. This happens because of capital market investors assume that the rise in energy prices is a sign of rising global demand, which means improving the global post-crisis economic recovery. That way, if the price of crude oil increases, improving performance against expectations the companies will also increase and its stock price will automatically join up. These results also correspond to the research of Lawrence (20/3) stating that world oil prices a positive effect against $\mathrm{JCl}$, so when world oil prices go up, then ride the $\mathrm{JCl}$, and vice versa if world oil prices down then $\mathrm{JCl}$ down. The coefficient of Dow Jones Index (LDJIA) on the stock price index of the mining sector (LIDXM) is positive with the coefficient value is as much as 0.852327 , that means every increase in the global oil price, it will increase the stock price index.

The result is on the short term, The coefficient of Dow Jones Index (LDJIA) on the stock price index of the mining sector (LIDXM) is positive with the coefficient value is as much as 0.852327 , that means every increase in the global oil price as much as $1 \%$ (ceteris paribus), it will increase the stock price index of the mining sector as

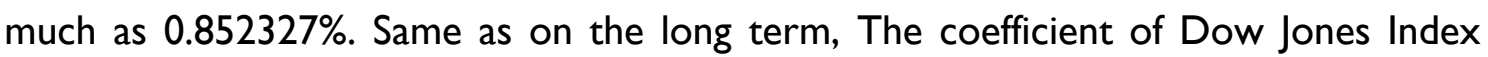
(LDJIA) on the stock price index of the mining sector (LIDXM) is positive with the coefficient value is as much as $\mathbf{0 . 4 7 0 4 3 9}$, that means every increase in the global oil price, it will increase the stock price index of the mining sector. The result has accepted hypothesis initial. This is related to the research by Sunariyah (20II) if the Dow Jones Index rising, its that means performance economy the United States participate will improve. We know Indonesia is one of the United States export destination so United States economic growth may encourage Indonesia's economic growth through export activities.

\section{CONCLUSION}

From the analysis, it can be concluded that Rupiah exchange rate in short term influenced negatively and not significantly the stock price index of the mining sector. In long term, Rupiah exchange rate also influenced negatively and significantly the stock price index of the mining sector. Meanwhile, the global gold price in short term influenced positively and not significantly the stock price index of the mining sector. In 
long term, the global gold price influenced negatively and significantly the stock price index of the mining sector. Then, the global oil price influenced positively and not significantly the stock price index of the mining sector in short term. In long term, the global oil price also influenced positively and not significantly the stock price index of the mining sector and finally, the Dow Jones Index in short term influenced positively and significantly the stock price index of the mining sector. In long term, the Dow Jones Index also positively and significantly influenced the stock price index.

By the existence of this research, the monetary authority is hoped to give more attention to the interest rate ( $\mathrm{Bl}$ Rate) in order that the society's interest in investment and saving can be maintained. The government is also hoped to be able to create a conducive investment climate in domestic in order to attract the local investors' intention in the stock market. One of ways is by maintaining the stability $f$ the Rupiah exchange rate. Meanwhile, for investors, they should always see the trend of the global gold price and of the global oil price. When the price shows an increasing trend, the investors are suggested to buy or to accumulate the stocks the mining sector.

\section{REFERENCES}

Achmad, D. \& I. Ramli. (20I3). The Changes in World Oil Prices, Monetary Factors, and Foreign Index Toward Composite Index Movement: Indonesian Case for the Period of 2005-20II. Journal of Modern Accounting and Auditing. 9(9): 50I510.

Agustin, S. (2016). Pengaruh Variabel Makro Ekonomi, Harga Emas dan Harga Minyak Dunia Terhadap IHSG: Studi Pada BEI 2009-2013 (The Effect of Macroeconomic Variables, Gold Price, and World Oil Price to Composite Stock Price Index at IDX 2009-20I3). ejournal Administrasi Bisnis. 2016.4 (2): $550-562$.

Gumilang, R.C., R.R. Hidayat, \& M.G.W. Endang NP. (2014). Pengaruh Kurs USD, Inflasi dan Suku Bunga SBI Terhadap Indeks Harga Saham Sektor Pertambangan di Bursa Efek Indonesia (The Impact of USD Exchange Rate, Inflation, and SBI Interest Rate to Stock Price Index at Mining Sector in Indonesia Stock Exchange). Jurnal Administrasi Bisnis (JAB). I4 (2): II I-I 20. 
Performance Analysis of Indonesia's...

Hastra Reza Satyatama, Riwi Sumantyo

Kewal, S.S. (20I2). Pengaruh Inflasi, Suku Bunga, Kurs, dan Pertumbuhan PDB terhadap IHSG (The Effect of Inflation, Interest Rate, Exchange Rate, and GDP Growth to Composite Stock Price Index). Jurnal Economica. 8 (I): 53-64.

Kilian, L. \& C. Park. (2007). The Impact of Oil Price Shocks on the U.S. Stock Market. Economic Working Paper: I- 32

Lawrence, S.S. (20I3). Pengaruh Variabel Makro Ekonomi dan Harga Komoditas terhadap Indeks Harga Saham Gabungan di Indonesia (The Influence of Macroeconomics Variables and Comodity Prices to Composite Stock Price Index in Indoesia). Jurnal Ekonomi. I (2): 18-23

Ono, S. (20II). Oil Price Shocks and Stock Markets in BRICs. The European Journal of Comparative Economics. 8(I): 29-45.

Prasetiono, W.D. (2010). Ánalisis Pengaruh Faktor Fundamental Ekonomi Makro dan Harga Minyak terhadap Saham LQ45 dalam Jangka Pendek dan Jangka Panjang (The Effect of Macroeconomic Fundamental Factors and Oil Price to LQ 45 Stock Price in Short-Run an Long-Run). Journal of Indonesian Applied of Economics. 4 (I): I I-25.

Sidarta, W. (20I0). Ekonomi Finansial (Financial Economics). Jakarta: Erlangga

Sirucek, M. (20I2). Macroeconomic Variabels and Stock Market : US Review. International Journal of Computer Science and Management Studies. 12(3): 301-310.

Sunariyah. (20II). Pengantar Pengetahuan Pasar Modal (The Introduction to Capital Market).Yogyakarta: UP-STIM YKPN.

Tjandrasa, B.B. \& R. Sutjiati. (2016). Effect of World Gold Price, Crude Oil Price and Interest Rate to Jakarta Composite Index. International Journal of Education and Research. 4 (7): 215-222.

Yuswandi, Y. (2012). Analisis Pengaruh Harga Minyak Dunia, Harga Emas Dunia, Nilai Tukar Rupiah terhadap USD dan Indeks IHSG Terhadap Return Saham: Studi Kasus Saham-saham Sinarmas Group (The Effect of World Oil Price, World Gold Price, Exchange Rate and Composite Stock Price Index to Stock Retun: Case Study at Sinarmas Group Stocks). Jurnal Keuangan dan Perbankan. I(I): $230 I-2333$ 